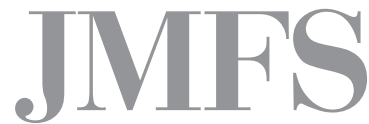

Journal of Management and Financial Sciences
Volume X

Issue 30 (December 2017)

pp. 91-114

Warsaw School of Economics

Collegium of Management and Finance

Waldemar Rogowski

Collegium of Business Administration

Warsaw School of Economics

\title{
Payment Delays: Their Reasons, Scale and Consequences
}

ABSTRACT

The paper discusses theoretical and practical aspects of a relevant and pertinent issue of the reasons behind late payments in $\mathrm{B} 2 \mathrm{~B}$ commercial transactions and their consequences. It aims at identifying reasons for late payments and pinpointing their economic consequences and costs. It also addresses the scale of the phenomenon, especially for payments overdue by more than 60 days, considered the most dangerous for regular performance of enterprises. The paper provides the results of studies on these aspects quoted in three most important reports by the following companies: Bisnode D\&B, Atradius, Intrum Justitia. It formulates conclusions on both the reasons and consequences of late payments in $\mathrm{B} 2 \mathrm{~B}$ commercial transactions.

Keywords: late payment, payment delay, reasons behind late payments, consequences of late payments, costs of late payments, scale of late payments

JEL Codes: G 32 G 33, and G 35 


\section{Introduction}

The research problem discussed in the paper focuses on the identification of the reasons, consequences (effects), and scale of late payments in the Polish economy compared to other, mainly European, countries. Deferred payment arrangements are a popular solution widely applied in B2B transactions (in EU Member States they are used in almost $50 \%$ of B2B sales), which nevertheless imply a classical credit risk (late or no payment). Hence exposure to risk is an inherent feature in businesses which offer deferred payment arrangements to their clients. To many enterprises in Poland, the practice of postponing the deadline for payment is part of their everyday reality and it determines the level of risk involved in doing business. Untimely payments may lead to the loss of profitability, liquidity and even to insolvency, which often ends in bankruptcy. The scale of late payments remains to be big, in Poland and globally, which is confirmed by reports of companies, such as Intrum Justitia, Atradius or Bisnode Dun \& Bradstreet. According to the Bisnode Dun \& Bradstreet's report, in 2016 on average $62 \%$ of businesses in Europe declared payment delays. In Poland the proportion was $57.5 \%{ }^{1}$. Late payments exert a negative or even highly destructive impact upon the performance of individual businesses, industries, sectors or economies. The issue is very important to participants or animators of economic reality. Hence, it remains a pertinent and attractive area of research explorations, both in theoretical (research) and practical (application) dimensions. The above premises were decisive for choosing this research area and identifying research problems. The paper contributes to better presentation and description of the main reasons and consequences of late payments and demonstrates their scale (in particular, payments overdue by more than 60 days $^{2}$ ) in Poland and in other countries.

Three research questions have been formulated to examine the subject:

1. What are the reasons for late payments? Are they universal or specific?

2. Is the scale of late payments the same or different in various countries?

3. What are direct and indirect consequences and costs implied by payment delays and payment backlogs?

1 Bisnode Dun \& Bradstreet, Global Payments Performance Barometer 2017, www.bisnode.pl/ blog/terminowosc-platnosci.../barometr-platnosci-na-swiecie [Polish language version], accessed on 20 May 2017.

2 As payments delayed by more than 60 days produce the most negative outcomes. 
These questions link directly to four main theses:

1. The reasons for late payments are universal across the globe and are not country-specific; neither are they specific for a particular size of business nor for the sector in which it operates.

2. However, the frequency with which the reasons for late payments occur depends on a geographic region, a country, size of a business, and the sector in which a business operates.

3. Payment delays produce diverse, yet only negative, consequences for business performance and growth, as well as for entire economies and societies.

4. Payments overdue by more than 60 days and uncollectible accounts are the most destructive for the stability and economic standing of companies suffering from late payments.

\section{Reasons for Late Payments}

Late payment is a payment that has not been paid on time, i.e. in which a payment delay is involved. A payment delay can be described as the amount of time that passes between the deadline for payment originally agreed by parties to a commercial transaction (e.g. in a contract) and the actual remittance of the payment that is due. Late payments can be divided into three groups:

1. late payments which have been paid, i.e. payments that have been made after the expiry of the deadline for payment specified in the contract;

2. late payments not yet paid - payments for which the payment deadline has expired but have not been made yet. In this case, the term overdue payment seems much more appropriate;

3. lost late payments - are payments not yet made that have been overdue for a long time and have become uncollectible because the clients (debtors) supposed to make them have gone, e.g., bankrupt.

Late payments, as often believed, are not just the effects of erroneous (wrong, incompetent) business conduct, especially with respect to granting trade credit or cultural aspects determining payment morale ${ }^{3}$. Structures of business relations and cooperation chains within which businesses operate in specific sectors (economic power of suppliers and their customers), norms and hierarchies, relative market power, business cycle, financial infrastructure (financing available from banks), and

3 Payment morale consists in proper payment conduct that translates into timely payment of one's liabilities (debts). 
the legal system (norms and regulations) are much more powerful determinants of the late payments phenomenon ${ }^{4}$. In an ideal world, where all solvent enterprises could have immediate and continuous access to finance from diverse sources, late payments would be very rare. Businesses offering deferred payment arrangements would take account of the risk directly in their operating costs and their partners, who realise these costs and benefit from such arrangements making payments as timely as possible. Obviously, such an ideal world is far from business reality, especially in the emerging markets ${ }^{5}$.

Thus, we may feel inclined to say that the reasons for late payments have their exo- and endogenous roots.

There are many different reasons involved. They may be due to a customer's bankruptcy, his/her bad will or market practices resulting from his/her market power (the client does not pay though his/her financial standing is good and (s)he could pay the liabilities on time), from disputes over the quality or characteristics of supplied products or services ${ }^{6}$.

When discussing the reasons behind late payments we must supplement theoretical considerations with the results of studies that explore the issue across countries and sectors, in which businesses of various sizes operate. We shall use data from reports by Atradius and Intrum Justitia, the companies that for more than a decade have been monitoring the reasons for late payments in European countries.

In the survey conducted by Atradius on payment delays in domestic B2B model in 2017, companies from Eastern and Western Europe most often selected Insufficient availability of funds as a reason why debtors were unable to make payments on time. The second most important reason given by businesses in Eastern and Western Europe was a purposeful strategy of Buyer using outstanding invoices as a form of financing (overdue liabilities). Interestingly, in Eastern Europe Formal insolvency of the buyer (bankruptcy) ranked third among the reasons for late payments. In Western Europe the same reason occupies the 6th position. Further three reasons are purely operational and link with errors in invoicing and mailing or with overcomplicated payment procedures. Thus, they are internal reasons, which may be eradicated by creditors if they put the right procedures in place. Another reason, i.e., Disputes over the quality of supplied products or services seems interesting and needs a closer

4 M. Schizas, Ending late payment Part 3: Reflections on the evidence, ACCA 2015c, http://www. accaglobal.com/content/dam/acca/global/PDF-technical/small-business/pol-tp-elp-3reflections.pdf, p. 6 .

5 M. Schizas, Ending late payment Part 3: Reflections on the evidence, ACCA 2015c, http://www. accaglobal.com/content/dam/acca/global/PDF-technical/small-business/pol-tp-elp-3reflections.pdf, p. 6 .

6 P. Białowolski, A. Łaszek, Zatory płatnicze duży problem dla małych firm, Forum Obywatelskiego Rozwoju, Publisher to FOR, Warszawa 2017, p. 6. 
examination. It may be part of a specific "game" played by the debtors to delay the payment, which would correspond with the second most often selected reason: Buyer using outstanding invoices as a form of financing (overdue liabilities) and with poor Administrative efficiency of Supplier (Creditor) - which may be both an external and internal reason. Undoubtedly, Inefficiencies of the banking system should be interpreted as an external reason.

Table 1. Reasons for payment delays in Eastern and Western European countries over the period 2015-2017

\begin{tabular}{|c|c|c|c|c|c|c|}
\hline Region: & \multicolumn{3}{|c|}{ Western Europe } & \multicolumn{3}{|c|}{ Eastern Europe } \\
\hline Reason: & 2017 & 2016 & 2015 & 2017 & 2016 & 2015 \\
\hline Insufficient availability of funds & $52.6 \%$ & $57.90 \%$ & $51.40 \%$ & $58.40 \%$ & $64.40 \%$ & $59.98 \%$ \\
\hline $\begin{array}{l}\text { Buyer using outstanding invoices as a form of } \\
\text { financing }\end{array}$ & $28.20 \%$ & $28.20 \%$ & $12.20 \%$ & $32.40 \%$ & $32.70 \%$ & $8.07 \%$ \\
\hline Formal insolvency of the buyer (bankruptcy) & $13.10 \%$ & $15.80 \%$ & $8.70 \%$ & $19.80 \%$ & $18.80 \%$ & $6.05 \%$ \\
\hline Complexity of the payment procedure & $18.20 \%$ & $17.20 \%$ & $16.30 \%$ & $13.40 \%$ & $13.00 \%$ & $13.34 \%$ \\
\hline Inefficiencies of the banking system & $12.80 \%$ & $12.50 \%$ & $11.80 \%$ & $11.20 \%$ & $8.50 \%$ & $11.43 \%$ \\
\hline $\begin{array}{l}\text { Disputes over the quality of supplied products or } \\
\text { services }\end{array}$ & $16.50 \%$ & $15.50 \%$ & $34.10 \%$ & $10.80 \%$ & $10.90 \%$ & $34.75 \%$ \\
\hline Incorrect information on the invoice & $12.20 \%$ & $11.40 \%$ & $15.30 \%$ & $9.80 \%$ & $10.50 \%$ & $8.97 \%$ \\
\hline $\begin{array}{l}\text { Goods delivered or services provided do } \\
\text { not correspond to what was agreed in the contract }\end{array}$ & $13.30 \%$ & $11.40 \%$ & $18.50 \%$ & $9.00 \%$ & $6.90 \%$ & $24.22 \%$ \\
\hline Invoice was sent to a wrong person (address) & $7.50 \%$ & $7.50 \%$ & $11.00 \%$ & $5.40 \%$ & $7.50 \%$ & $5.38 \%$ \\
\hline
\end{tabular}

Source: Atradius, Payment Practices Barometer 2015/2016/2017. Survey Results for Eastern Europe, and Atradius Payment Practices Barometer2015/2016/2017. Survey Results for Western Europe http://global.atradius.com/, accessed on 31.05.2017.

Tables $2 \& 3$ present the reasons for late payments reported by companies in Western and Eastern Europe against the sector in which they operate and their respective size. For the past 3 years, Insufficient availability of funds and Buyer using outstanding invoices as a form of financing were two main reasons indicated by micro, small, medium-sized and large companies. Hence, they are universal and common reasons independent of business size and sector.

When analysing the data from Tables 1-3, we may come to a conclusion that the reasons for payment delays are universal. Yet, specifically countries of Eastern Europe reported bankruptcy of their business partners as a valid reason for late payments from domestic B2B customers.

In the opinion of Polish enterprises, two universal reasons prevail with Insufficient availability of funds clearly gaining in importance in recent years. 


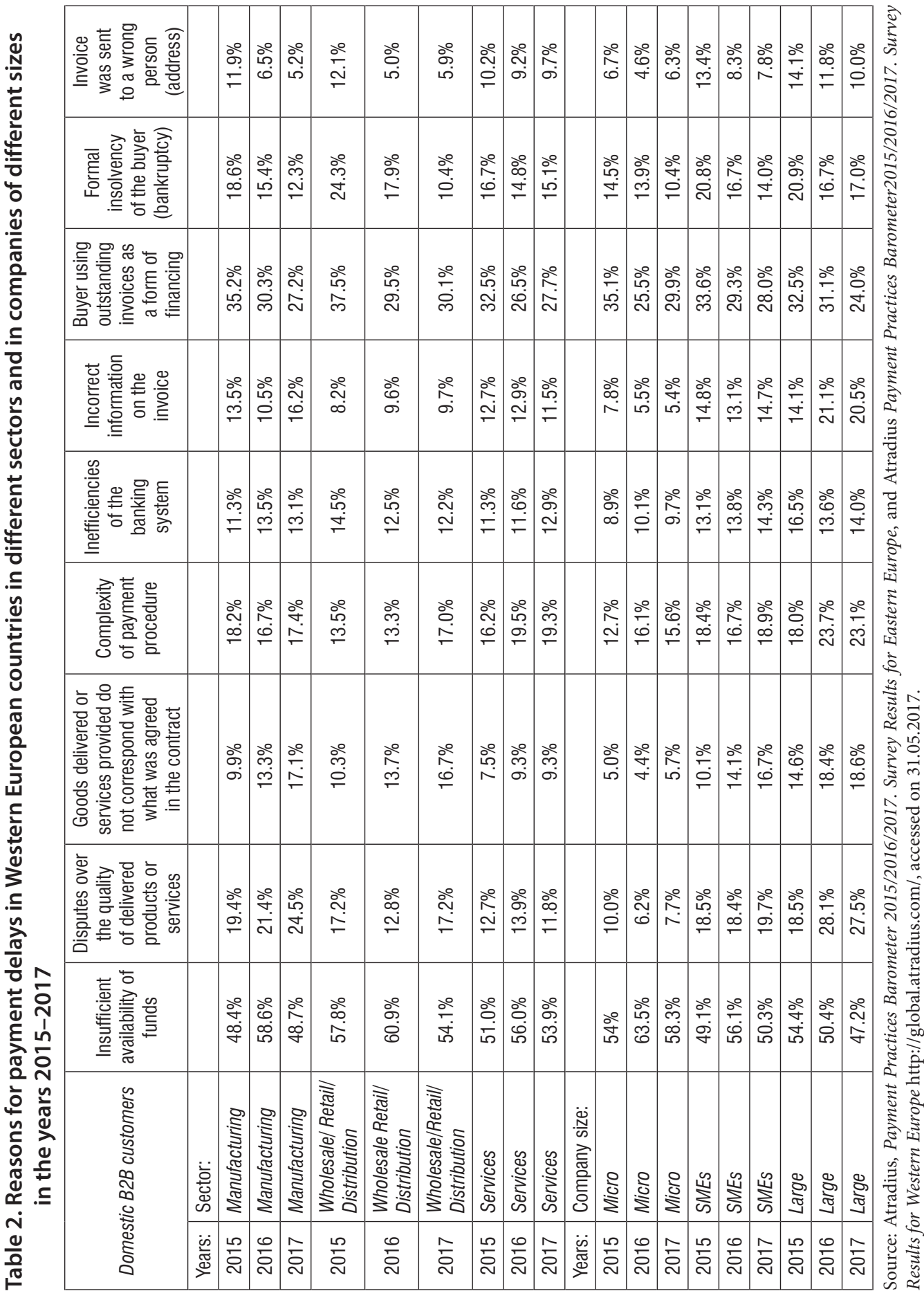




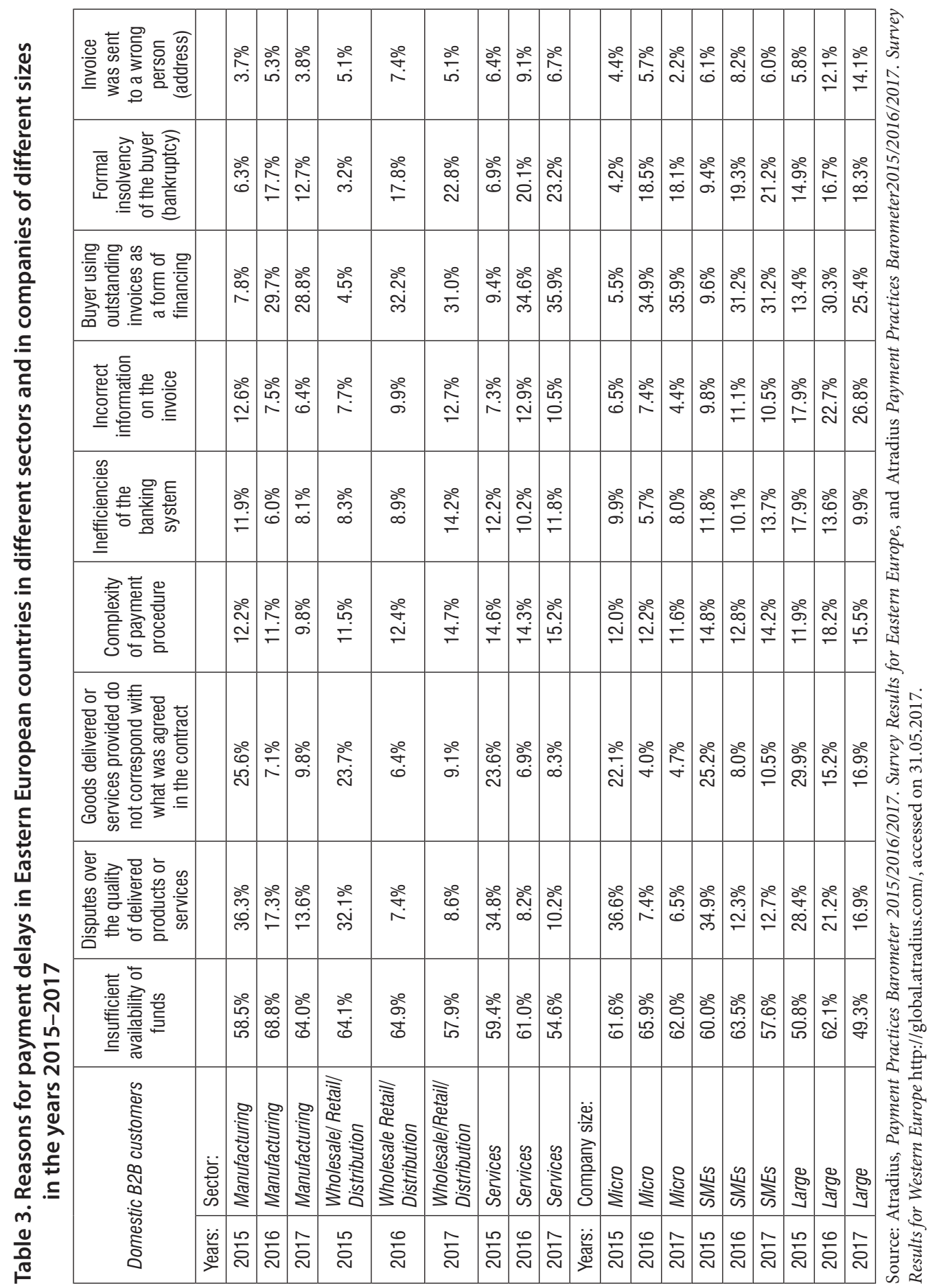




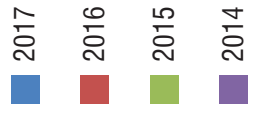
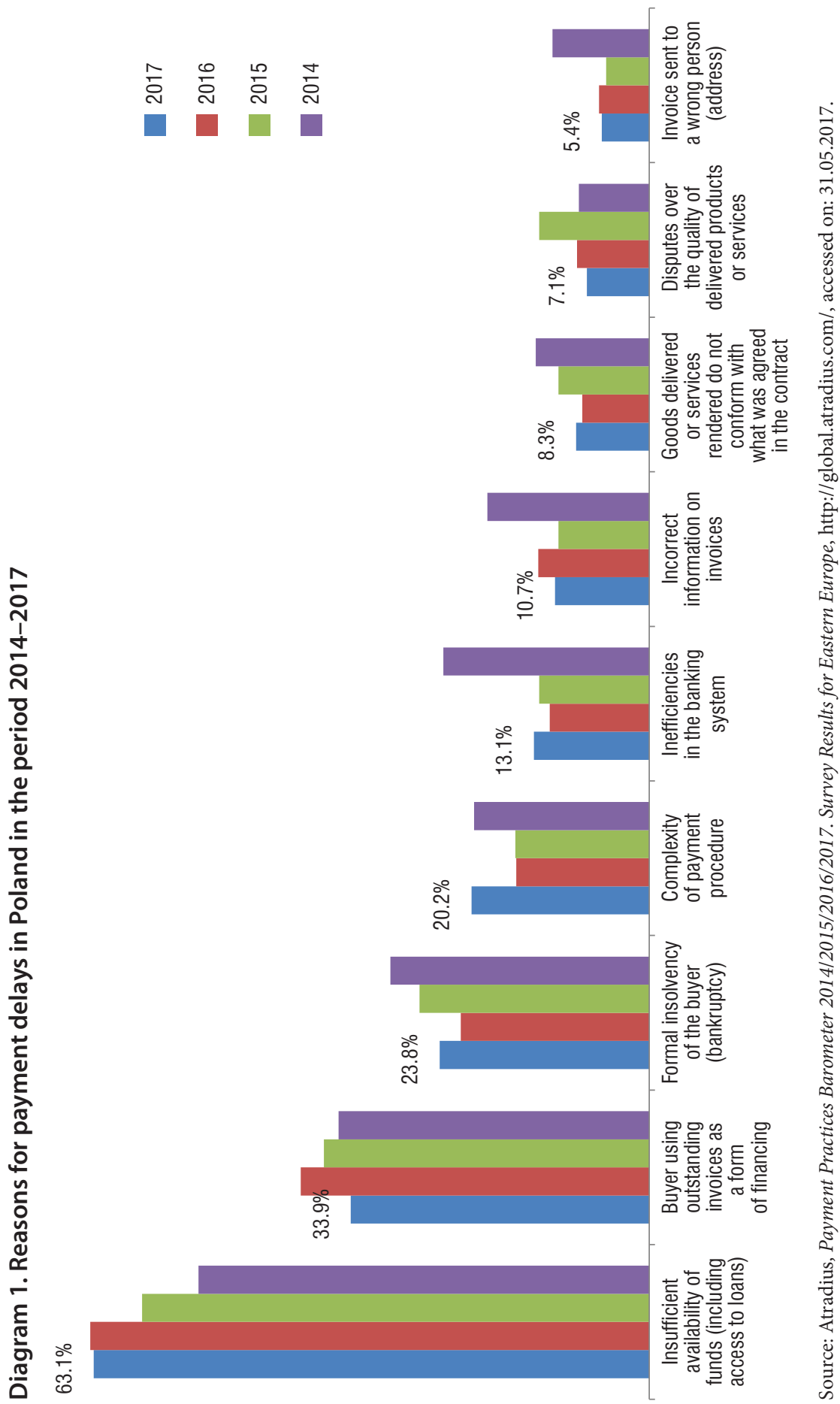


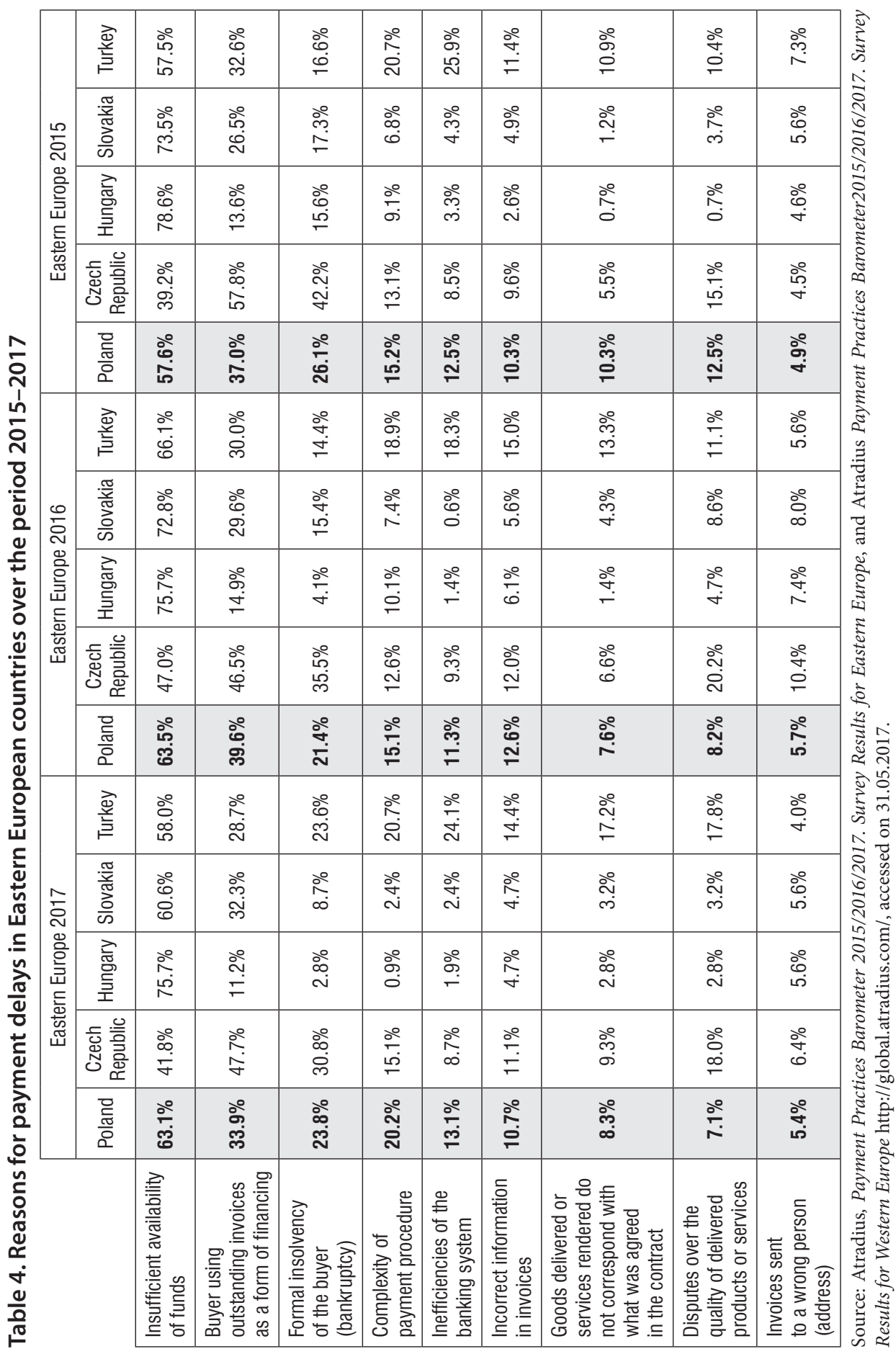


What differs Poland from other Eastern European countries is a high percentage of Insufficient availability of funds answers, which scored higher only in Hungary. Formal insolvency of the buyer (bankruptcy) was also often mentioned as a reason for late payments; a higher percentage was reported only in the Czech Republic. Surprisingly, Complexity of payment procedure scored over 20\%, similarly in Turkey, as most payments are online bank transfers for invoices sent mostly online.

\section{Diagram 2. Main reasons for payment delays in 2017}

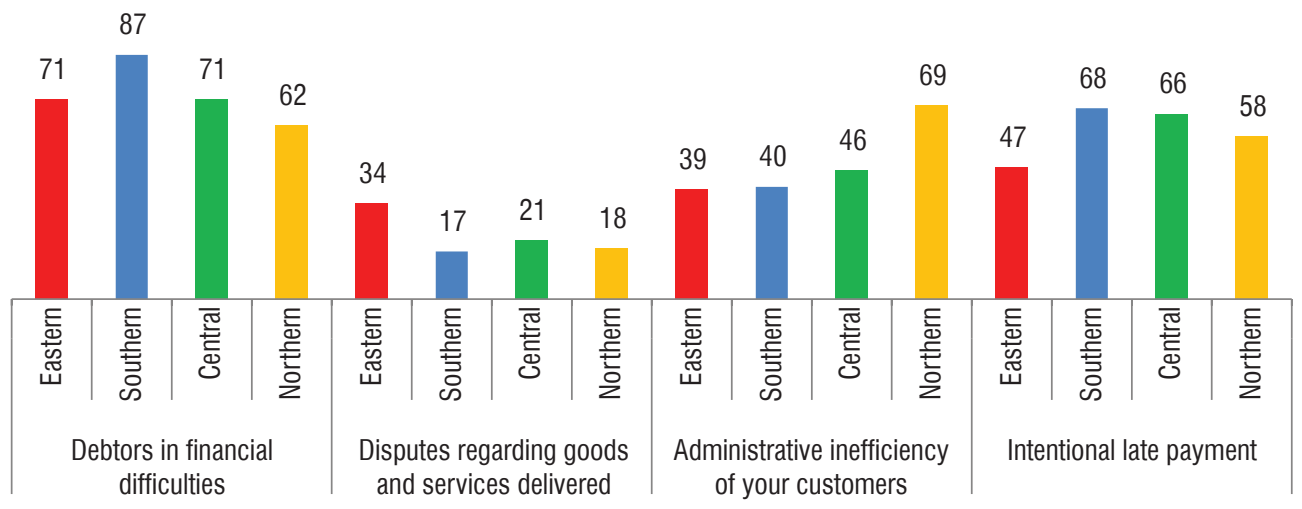

Source: Intrum Justitia, European Payment Index 2014-2017, http://www.intrum.com, accessed on 17.06.17.

In most European countries Debtors in financial difficulties are considered the main reasons for late payments. In some countries, such as: Denmark, Sweden, Norway, the United Kingdom, and Ireland administrative inefficiency of debtors is blamed for payment delays. In Poland, unlike in other countries, debtors in financial difficulties and intentional late payments are equally often mentioned as the reasons for payment delays.

The results of the survey conducted by Atradius confirm those obtained by Intrum Justitia. Both point to Debtors in financial difficulties and Intentional late payment as the main reasons for payment delays. Other reasons include Disputes regarding goods and services delivered and, interestingly, Operating (administrative) inefficiencies are mentioned but they are attributed to debtors (customers) not to the creditor as it is the case in Atradius' survey. That confirms universal nature of the reasons for late payments. The results obtained by Atradius and Intrum Justitia are also confirmed by Kantar Millwardbrown's survey commissioned by the InfoMonitor Economic Information Office [Polish: BIG - Biuro Informacji Gospodarczej]. Interestingly, the results of the survey suggest the main reason is Payment backlog followed by Debtors in financial difficulties and Intentional late payment. 
Table 5. Main reasons for payment delays in European countries in 2017

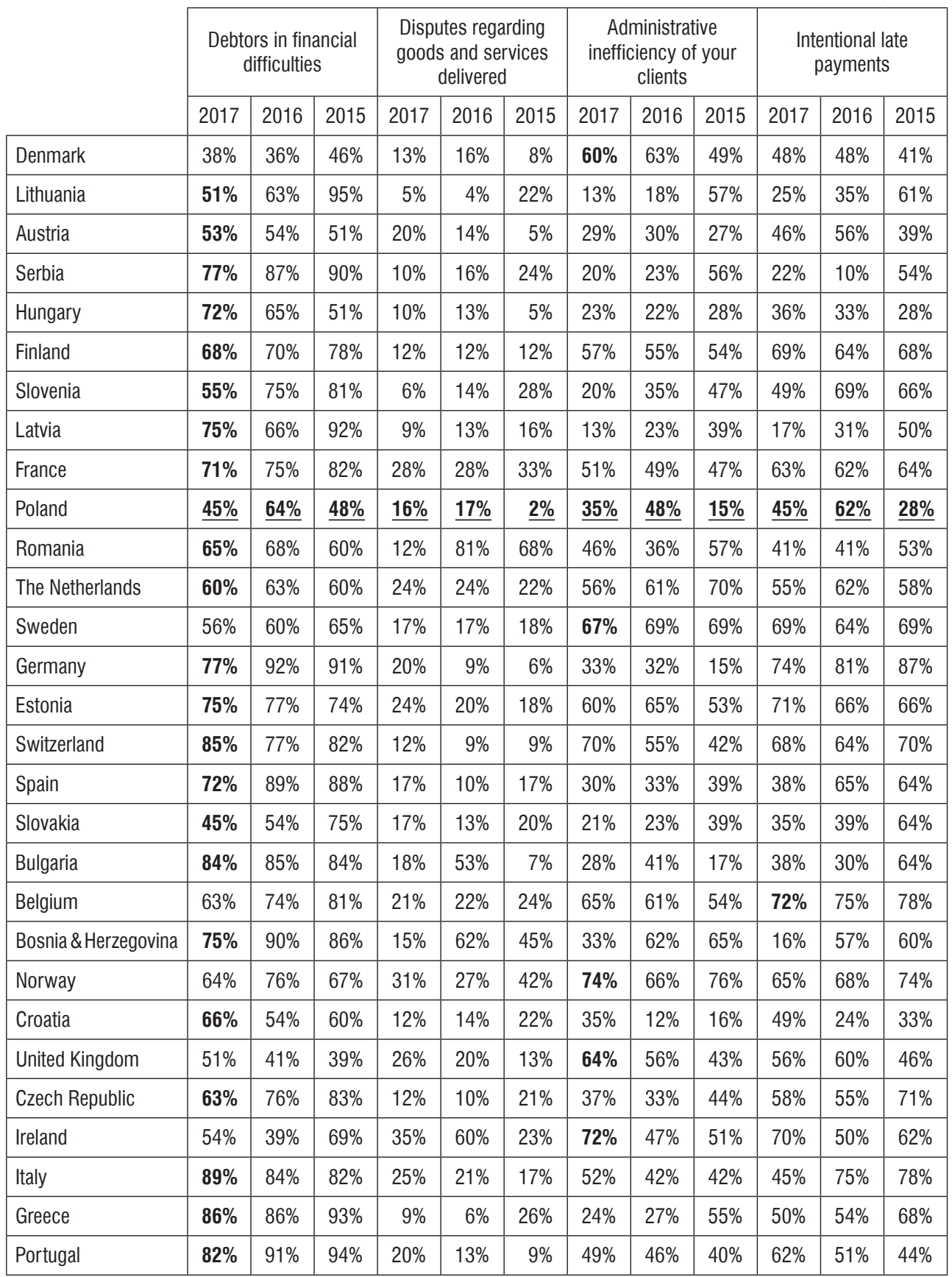

Source: Intrum Justitia, European Payment Index 2014-2017, http://www.intrum.com\%, accessed on 17.06.17. 


\section{Diagram 3. Reasons for payment delays (number of businesses selecting a particular reason)}

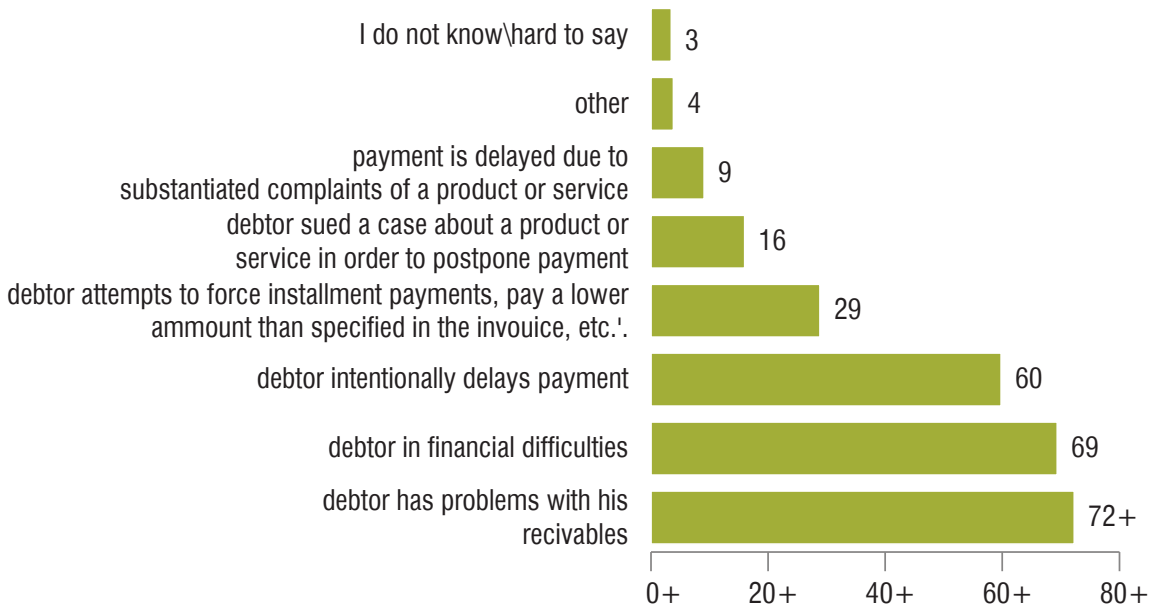

Source: Zatory Płatnicze w Polsce badanie, Kantar Millwardbrown for BIG Informonitor, Warszawa 2017, p. 6.

\section{Scale of Payments Delayed for over 60 Days}

When it comes to payments overdue for over 60 days - which cannot be considered natural and pose a real threat to everyday business and to the survival of companies that experience them - Poland performs much worse than other countries. According to the studies conducted by Bisnode Dun \& Bradstreet in 2016, as many as $20 \%$ of Polish companies suffered from payments delayed for over 60 days, which earned the country no. 2 position in this shameful ranking in Europe, immediately after Romania.

A less pessimistic outlook for companies whose receivables are late by over 60 days is painted by Atradius' survey. Its latest report shows that such delays were experienced by only $8 \%$ of companies in Poland.

Thus, it is worth juxtaposing the results of surveys conducted by the two companies with other surveys. According to Kantar Millwardbrown's survey commissioned by the BIG InfoMonitor at the end of 2016, 11\% firms delayed payments for over 60 days $^{7}$. On the other hand, statistical data from BIG InfoMonitor database ${ }^{8}$ at the end of December 2016 indicated that $4.4 \%$ companies had liabilities late by more

7 BIG InfoMonitor, Raport Indeks Zatorów Płatniczych, December 2016, p. 2.

8 Liabilities from InfoMonitor database cover only liabilities other than loans. 
than 60 days of the minimum amount of PLN $500^{9}$. Although the situation is different in different sectors, relatively ${ }^{10}$ the biggest number of such companies could be found in Water supply, sewerage, waste management, and remediation activities, while the fewest originated from Public administration and in Human health.

\section{Diagram 4. Percentage of companies with payments delayed for over 60 days in 2016}

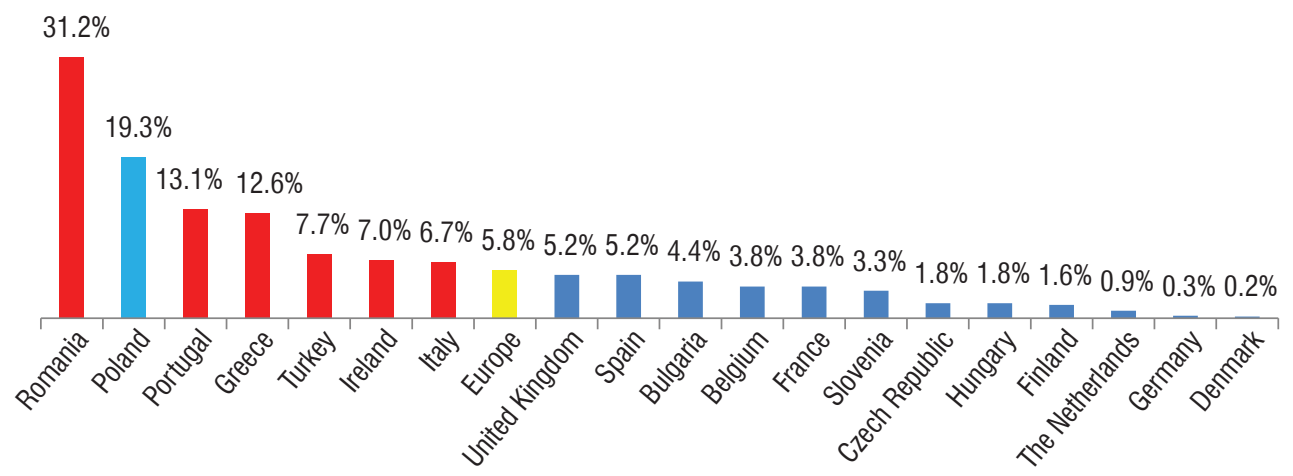

Source: Bisnode Dun \& Bradstreet, Barometr płatności na świecie 2017, www.bisnode.pl/blog/terminowosc-platnosci.../ barometr-platnosci-na-swiecie, accessed on 20.05.2017.

\section{Diagram 5. Percentage of companies with receivables delayed by over 60 days} in 2016

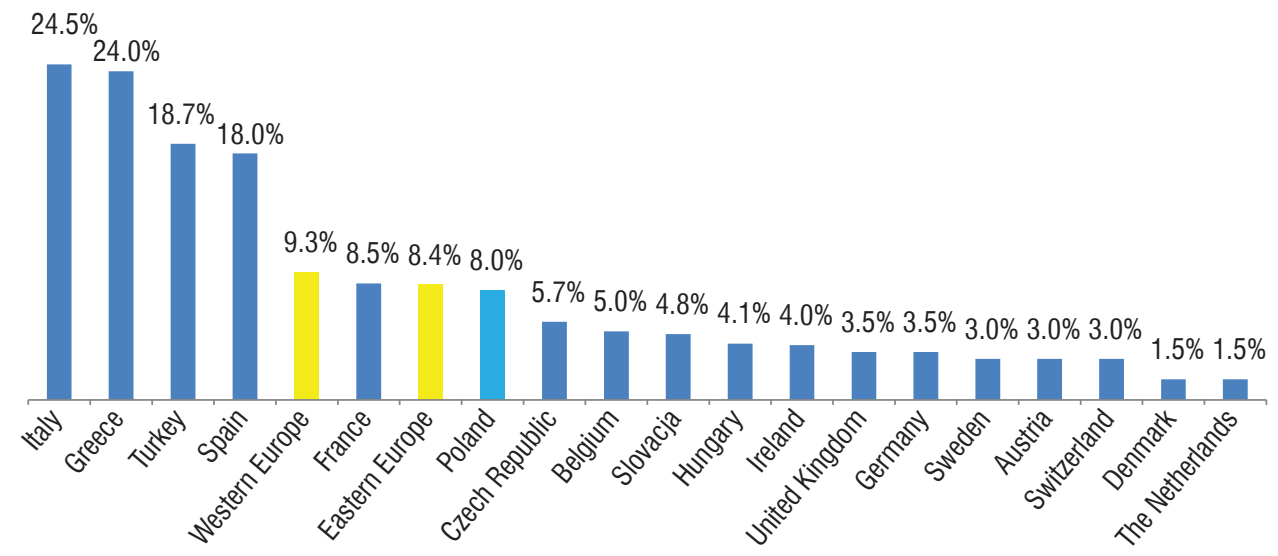

Source: Atradius, Payment Practices Barometer 2017. Survey Results for Eastern Europe, and Atradius Payment Practices Barometer 2017. Survey Results for Western Europe http://global.atradius.com/, accessed on 31.05.2017.

\footnotetext{
${ }^{9}$ Late payments do not include late payments of bank loans.

${ }^{10}$ Share of companies from a particular section with minimum payments of PLN 500 late by more than 60 days in the total population of businesses in a given section.
} 
Table 6. Proportion of enterprises with the minimum amount of liabilities of PLN 500 late by more than 60 days in individual sectors at the end of 2016

\begin{tabular}{|l|l|}
\hline Total of all sections & $4.4 \%$ \\
\hline A Agriculture, forestry and fishing & $3.1 \%$ \\
\hline B Mining and quarrying & $6.8 \%$ \\
\hline C Manufacturing & $4.8 \%$ \\
\hline D Electricity, gas steam and air conditioning supply & $3.3 \%$ \\
\hline E Water supply, sewerage, waste management and remediation activities & $7.6 \%$ \\
\hline F Construction & $5.4 \%$ \\
\hline G Trade; repair of motor vehicles & $5.0 \%$ \\
\hline H Transportation and storage & $6.5 \%$ \\
\hline I Accommodation and catering & $5.8 \%$ \\
\hline J Information and communications & $3.6 \%$ \\
\hline K Financial and insurance activities & $5.0 \%$ \\
\hline L Real estate activities & $3.8 \%$ \\
\hline M Professional, scientific and technical activities & $2.9 \%$ \\
\hline N Administrative and support services & $4.4 \%$ \\
\hline O Public administration and defence, compulsory social insurance & $0.1 \%$ \\
\hline P Education & $2.0 \%$ \\
\hline Q Human health and social work activities & $1.1 \%$ \\
\hline R Arts, entertainment and recreation & $3.5 \%$ \\
\hline S Other services & $2.2 \%$ \\
\hline
\end{tabular}

Source: BIG InfoMonitor database, accessed on 31.05.2017.

The geographic distribution of companies in Poland whose payments are late by over 60 days is also worth examining. The biggest percentage of such companies can be found in Śląskie Province - 6.1\% and in Kujawsko - Pomorskie - 5.7\%, the smallest in provinces in South- Eastern Poland: Podkarpackie - 3.4\%, Podlaskie - 3.6\%, and Małopolskie - $3.7 \%$. Payment morality of Polish companies is differentiated and depends on their location. Undoubtedly, it is influenced by cultural aspects connected with traditional, conservative values typical of South-Eastern Poland. A similar differentiation can be observed when looking at loan repayment performance of micro-entrepreneurs and individuals, which is confirmed by numerous analyses of the Credit Information Bureau [PL: Biuro Informacji Kredytowej].

Moreover, we need to note that the number of companies whose accounts receivable are late by over 60 days differs depending on the size of an enterprise. According to the survey conducted by Bisnode Dun \& Bradstreet, almost every fifth micro-entrepreneur reported payments late by over 60 days while among large companies 
the problem affected only every twentieth business. Thus, we may conclude that the smaller a company the higher the percentage with accounts late for more than 60 days.

Diagram 6. Share of companies from a given province with payments of minimum PLN 500 late by more than 60 days in the total business population in a province at the end of 2016

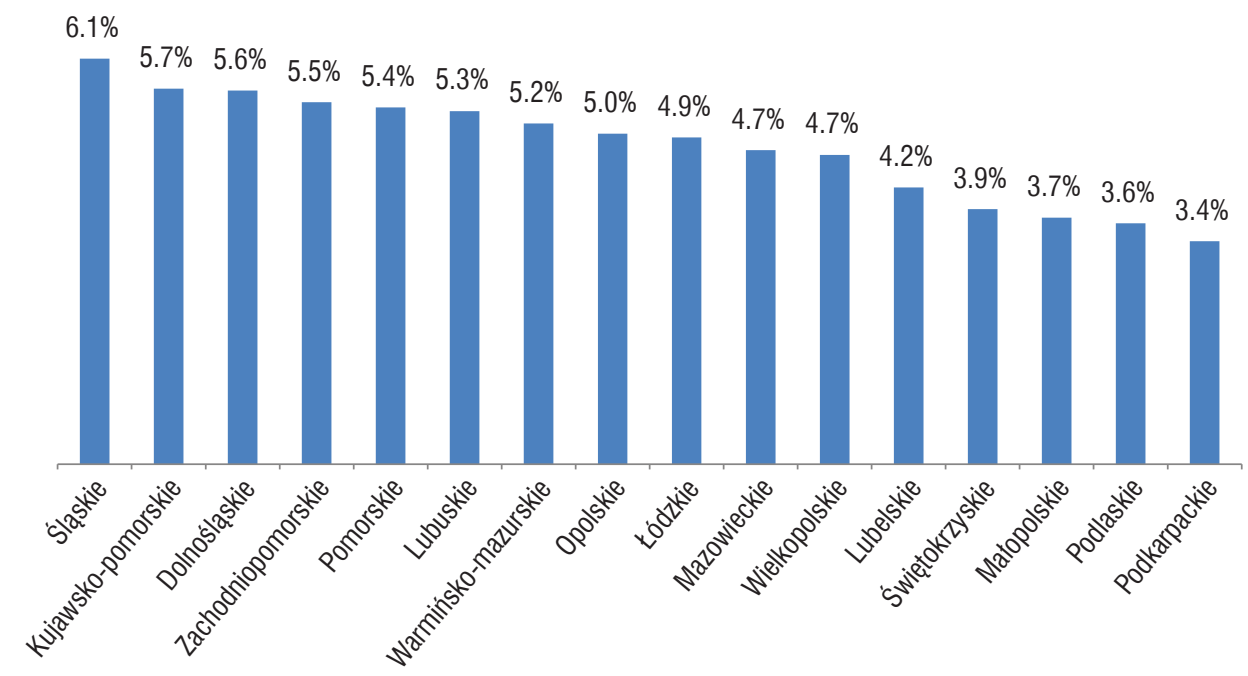

Source: BIG InfoMonitor database, accessed on 31.05.2017.

Diagram 7. Share of enterprises in Poland in 2016 with payments late by more than 60 days by business size

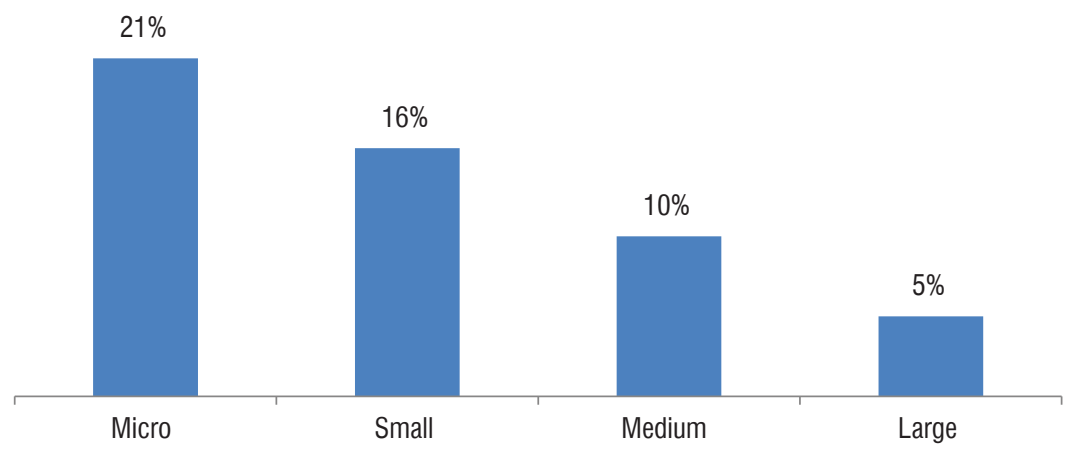

Source: Bisnode Dun \& Bradstreet, Barometr płatności na świecie 2015/2016/2017, www.bisnode.pl/blog/terminowosc-platnosci.../barometr-platnosci-na-swiecie, accessed on 20.05.2017.

Interestingly enough, besides Romania and Greece only Poland has got such a high percentage of micro-entrepreneurs with payments late by over 60 days. 
Unfortunately, the surveys conducted by Bisnode Dun \& Bradstreet and Atradius confirm the growing number of companies with accounts receivable late by more than 60 days in Poland.

\section{Diagram 8. Share of companies with payments delayed by more than 60 days} in Poland from 2011 until 2016

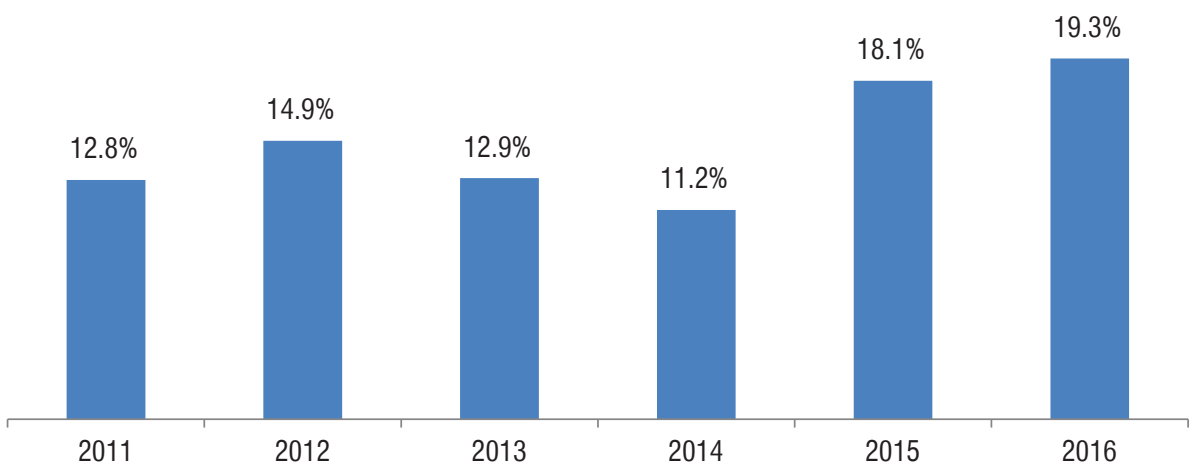

Sources: Bisnode Dun \& Bradstreet, Barometr płatności na świecie 2015/2016/2017, www.bisnode.pl/blog/terminowosc-platnosci.../barometr-platnosci-na-swiecie, accessed on 20.05.2017.

Diagrams 9. Structure of payments delayed by over 60 days in Poland from 2014 until 2016, domestic business partners

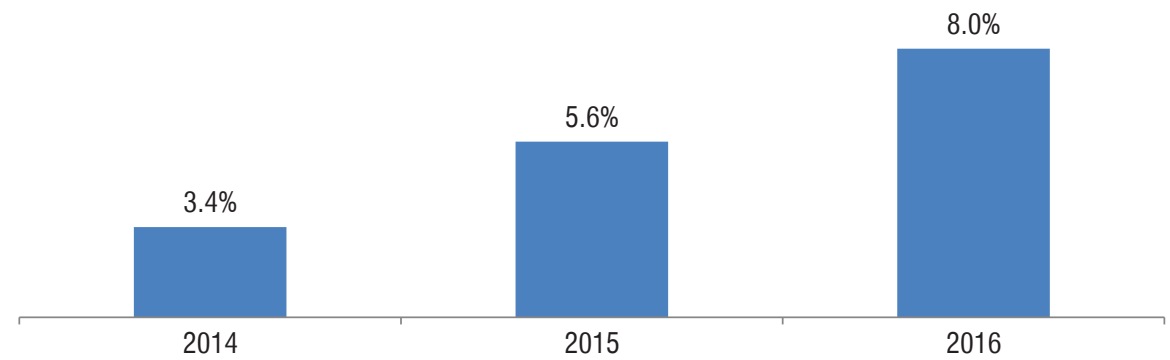

Source: Atradius, Payment Practices Barometer 2015/2016/2017. Survey Results for Eastern Europe, http://global. atradius.com/, accessed on 31.05.2017.

\section{Consequences of Late Payments}

As much as we can identify the reasons for late payments, we can also point to their consequences and costs entailed by them. The consequences are only negative as they are directly linked with the need to bear additional costs of business operations and indirectly with the cost of the lost opportunity. If a company had 
no expenses related to late payments, the funds could be spent on its growth. Hence, it is necessary to identify the effects of late payments. However, the identification of total costs of late payments, i.e., real expenses and the lost opportunity, is a real challenge as they are not distinguished explicitly in books of accounts. To calculate them, we must carry out a questionnaire study among entrepreneurs.

We may not limit costs of late payments to direct costs connected with maintaining financial liquidity by businesses with a high share of overdue accounts receivable, which is why their revenue from sales does not generate cash inflows. They must finance their current operations with debt capital (loans and borrowings), for which they pay interest rates, which, in turn, reduces profitability of their business and engaged capital. Companies also pay high costs of monitoring late payments from their business partners and costs of their collection. Untimely payments from business partners produce real hurdles to the growth of businesses and, ultimately, may even lead to their closure or bankruptcy. J. Shopowski argues that one out of four bankruptcies in the EU was caused by late payments for goods delivered or services rendered, which led to the loss of almost 450,000 jobs annually ${ }^{11}$. We should not forget alternative costs reflected in reduced investment activity caused by disturbances in financing current operations ${ }^{12}$. That is confirmed by P. Białowolski and A. Laszek, who, basing on conducted desk studies, clearly indicate that late payments and payment backlogs exert a negative impact upon economic growth and make investing more difficult ${ }^{13}$.

Further negative outcomes of late payments are identified by S. Grzelczak, who claims that untimely payment or non-payment induces business community to think that they should not trust other entrepreneurs, even their long-term business partners. Hence, it is safer and more convenient to request cash prepayments for products or services or to consider moving the business abroad where payment morality is higher. As a result, there is an overall mistrust, positive relationships and economic links decay and they get replaced with suspicion and mistrust, which instigate safeguard clauses and intensive legal assistance. That, in turn, increases the cost of doing business and, in extreme cases, leads to a growing wave of bankruptcies. All these factors impede growth ${ }^{14}$.

11 J. Shopovski, Late Payments in Commercial Transactions in the European Union: Are we Getting Better? "European Journal of Scientific Research" ISSN 1450-216X / 1450-202X vol. 140, no 4, July 2016, pp. 436-447, http://www.europeanjournalofscientificresearch.com, p. 438.

12 P. Białowolski, A. Łaszek, Zatory płatnicze duży problem dla małych firm, Forum Obywatelskiego Rozwoju, Warszawa 2017, p. 6.

${ }_{13}$ P. Białowolski, A. Łaszek, Zatory płatnicze duży problem dla małych firm, Forum Obywatelskiego Rozwoju, Warszawa 2017, p. 13.

${ }^{14}$ S. Grzelczak, Ochrona praw wierzycieli w Polsce. Kwestia transparentności i dostępności informacji, Biuletyn PTE no. 4/2016, p. 38. 
As we should not examine the consequences of late payments only at the theoretical level, we need to conduct questionnaire based studies to identify these effects. To this end, we may use an international survey conducted by Intrum Justitia. According to the latest edition of the survey from 2017, the major global consequences of late payments included: limited (reduced) liquidity indicated by $42 \%$ of companies, loss of income (lost opportunity cost) (40\%), reduced growth potential (33\%), additional external costs (29\%), threat to the survival of the business (27\%), not hiring new staff (25\%), and the need to lay off staff (19\%).

\section{Diagram 10. Consequences of late payments to companies}

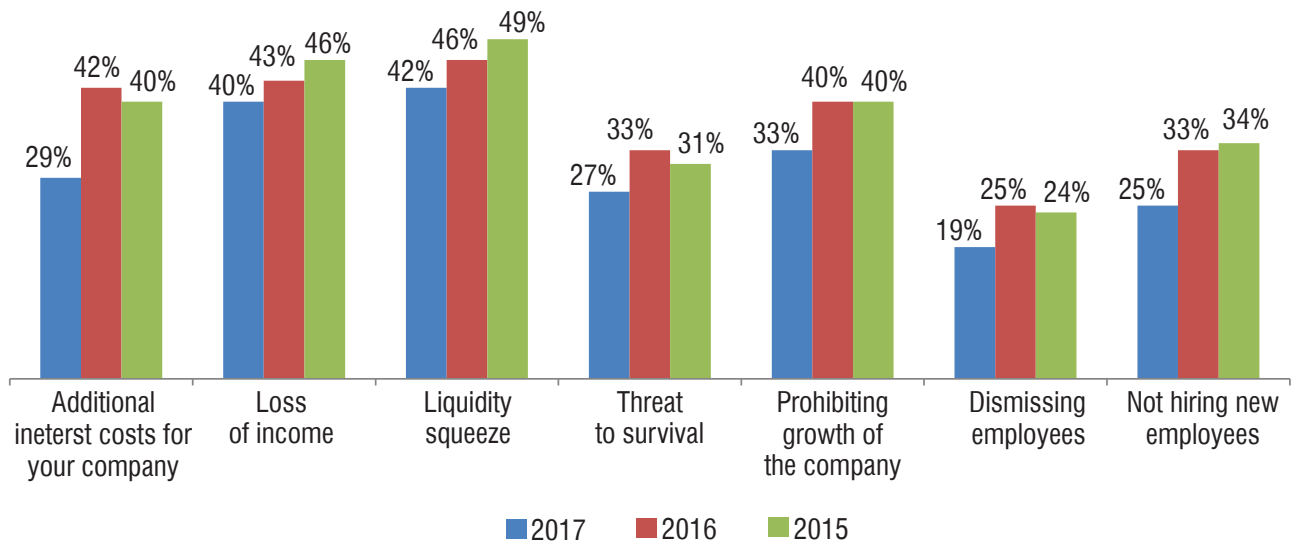

Source: Intrum Justitia, European Payment Index 2014-2017, http://www.intrum.com, accessed on 17.06.17.

\section{Diagram 11. Consequences of late payments depending on the country of a company's origin (2017) in \%}

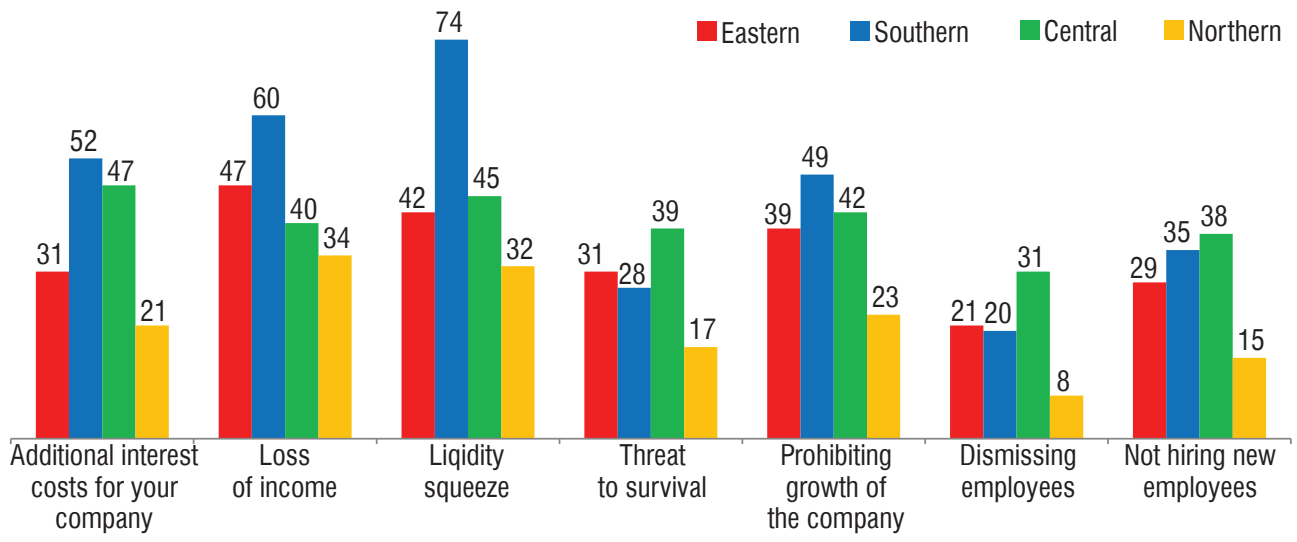

Source: Intrum Justitia, European Payment Index 2014-2017, http://www.intrum.com, accessed on 17.06.17. 
Remarkably, individual consequences of late payments depend on the region of Europe from which a company originates. The biggest consequences of late payments are experienced by companies from Southern Europe, while the smallest in Northern Europe. Surprisingly, liquidity squeeze is the major consequence for companies from the South of Europe ( $74 \%$ of indications) and from Central Europe (45\%). For companies from Northern and Eastern Europe loss of income is more important than liquidity squeeze.

Besides identifying the consequences of late payments, we should also examine how they impact businesses. The data in Diagram 12 is rather surprising. For five out of seven consequences a high and medium impact is very close and ranges between $35 \%$ and $39 \%$.

\section{Diagram 12. Consequences of late payments for companies by the strength of impact - 2017}

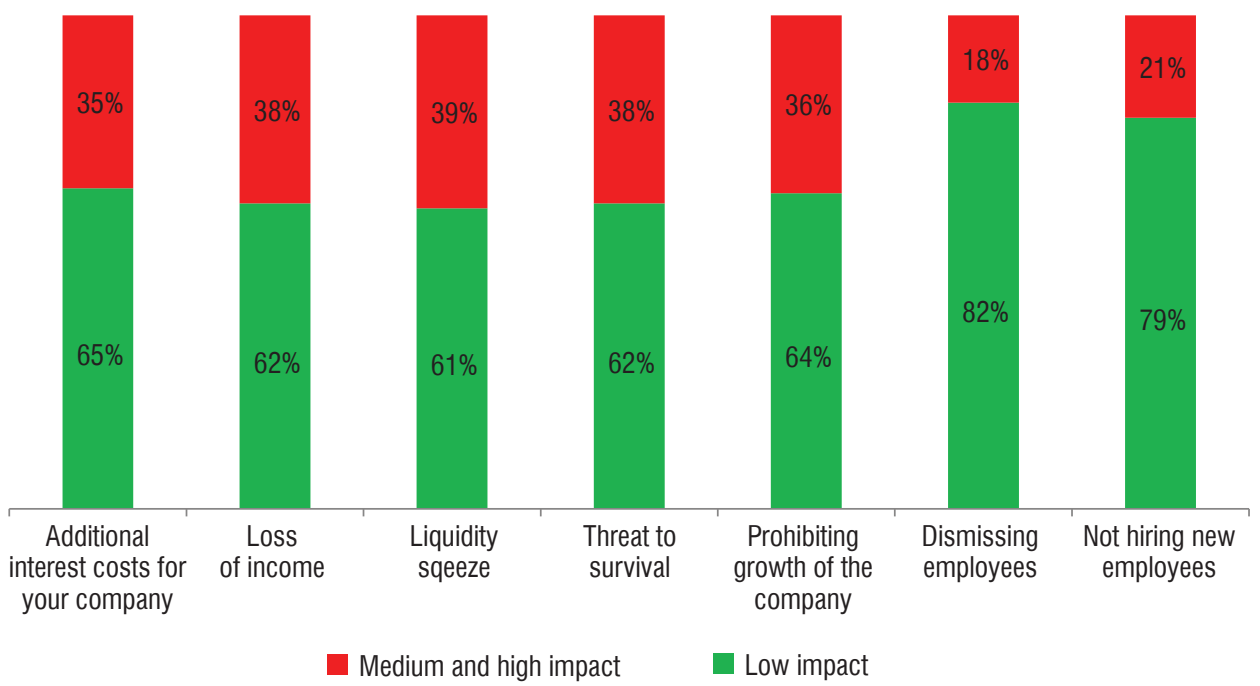

Source: Intrum Justitia, European Payment Index 2014-2017, http://www.intrum.com, accessed on 17.06.17.

The first cyclical study in Poland which identifies the consequences of late payments is the Portfel należności polskich przedsiębiorstw [Portfolio of accounts receivable of Polish enterprises] conducted since 2009. It not only allows assessing the impact of payment delays upon operating costs of enterprises but also the consequences of delays for companies. The survey is a joint project of the National Debt Register of the Economic Information Office SA [PL: Krajowy Rejestr Długów Biura Informacji Gospodarczej SA] and the Conference of Financial Companies in Poland [PL: Konferencja Przedsiębiorstw Finansowych w Polsce]. Based on average results 
of the survey for the period 2015-2016, P. Białowolski and A. Easzek presented the consequences of payment delays as identified by Polish companies. The most frequent consequence of late payments is payment backlog. As many as $27.9 \%$ of enterprises mention difficulties in paying their own liabilities due to untimely payments made to them by their customers. The second and much less intensive effect is the need to restrict investment activities. It is experienced by $26.8 \%$ companies in the country. Other consequences are less relevant. For the reasons pertaining to late payments 7.5\% companies in Poland declare that they had to refrain from placing new products on the market and $7.2 \%$ had to reduce employment or wages; $4.5 \%$ enterprises were forced to increase prices ${ }^{15}$.

Similar, although slightly different consequences of delays in their accounts receivable are identified by Polish companies in the study conducted on a regular basis by Intrum Justitia. In its latest edition in 2017 Polish companies that experience a high and medium impact of a particular consequence upon their current operations mentioned four main consequences, which they experience at almost equal levels: liquidity squeeze (for 39\% companies its impact is medium and high), loss of income (38\%), reduced growth potential (38\%), and threat to survival (36\%).

Diagram 13. Consequences of late payments to Polish companies by the strength of impact (from medium to high)

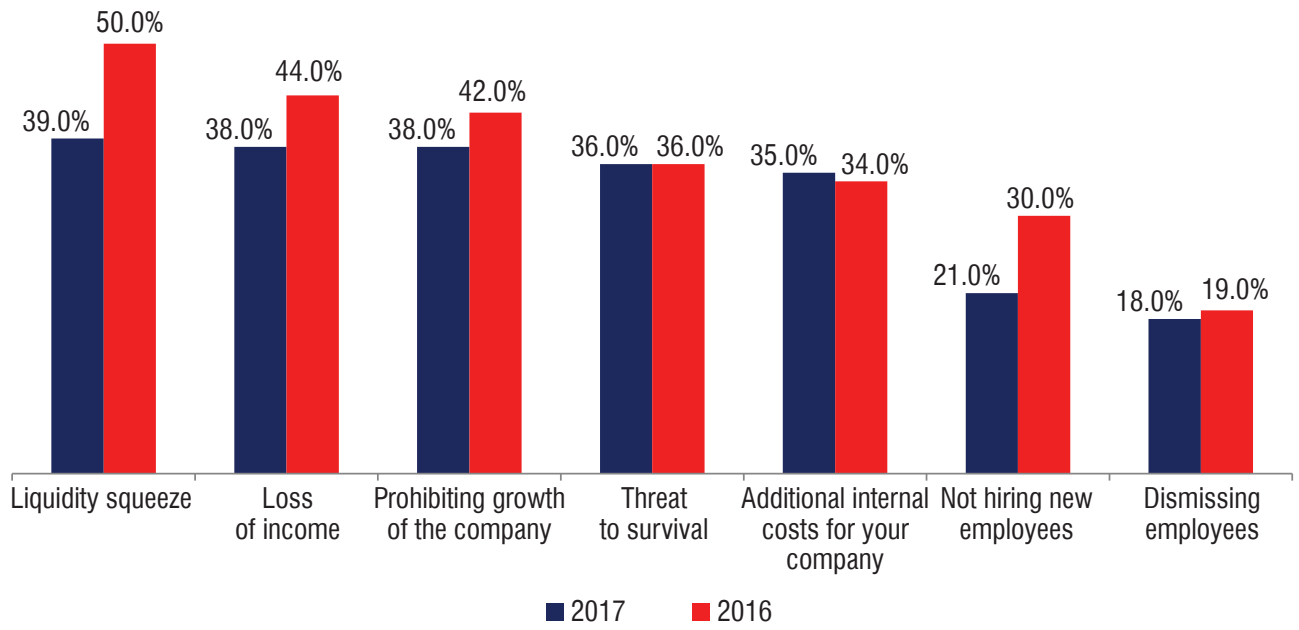

Source: Intrum Justitia, European Payment Index 2014-2017, http://www.intrum.com, accessed on 17.06.17.

${ }_{15}$ P. Białowolski, A. Łaszek, Zatory płatnicze duży problem dla małych firm, Forum Obywatelskiego Rozwoju, Warszawa 2017, pp. 26-27. 
Under the Portfolio of accounts receivable of Polish enterprises study the authors examined costs born by enterprises as a consequence of late payments. Within the framework of the study, costs of late payments to enterprises include: (1) losses resulting from non-payment, (2) costs of interest, (3) costs of debt monitoring and collection, (4) costs of extensive legal procedures designed to reduce the exposure to payment delays, (5) costs of withdrawing from some highly risky markets. The distribution of costs entailed by late payments, as well as their average value by groups of enterprises of a certain size from selected industries, are presented in Table 7. Costs of late payments to the whole economy reach 6.3 of total costs paid by enterprises every year. The total cost entailed by payment delays exceeds PLN $100 \mathrm{bn}^{16}$.

Table 7. Distribution of costs entailed by late payments

\begin{tabular}{|l|c|}
\hline \multicolumn{1}{|c|}{ Section } & Costs entailed by delays in \% \\
\hline Agriculture & 6.6 \\
\hline Industry & 4.1 \\
\hline Construction & 8.4 \\
\hline Trade & 5.3 \\
\hline Finance & 10.4 \\
\hline Telecoms & 8.2 \\
\hline Services & 7.3 \\
\hline \multicolumn{1}{|c|}{ Company size } & Costs entailed by delays in \% \\
\hline Micro & 8.0 \\
\hline Small & 5.5 \\
\hline Medium & 3.9 \\
\hline Large & 3.3 \\
\hline
\end{tabular}

Source: P. Białowolski, A. Łaszek, Zatory płatnicze duży problem dla małych firm, Forum Obywatelskiego Rozwoju, Warszawa 2017, p. 25.

Enterprises in construction and telecom industries must be prepared to face high costs exceeding $8 \%$. In the construction industry problems are most probably linked with the specificity of the sector, where birth and death rates of companies are very high and quite a big proportion of revenue is generated in the shadow economy. For telecom companies costs are also due to the dispersed population of their customers, which disturbs monitoring and an efficient collection of receivables. In most cases amounts involved in overdue payments are small, which means their collection is little

16 P. Białowolski, A. Łaszek, Zatory płatnicze duży problem dla małych firm, Forum Obywatelskiego Rozwoju, Warszawa 2017, pp. 24-26. 
profitable. The smallest costs of payment delays burden manufacturing companies. They are slightly higher than $4 \%$ of total costs. This is surely the effect of their stable portfolios composed of large clients, who are easy targets for monitoring and can be pressed if they are in delay. Medium-sized and large companies much more effectively manage their costs entailed by late payments and they can reduce them to less than $4 \%$. In large companies costs of payment delays are even lower and on average amount to only $3.3 \%$, i.e. by over $70 \%$ less than in micro-businesses. It makes the life of enterprises operating at a big scale significantly easier and improves their abilities to cope with market hardships. In general, micro companies pay the highest cost of payment delays of their business partners, which is why they are the most affected by the problem. Even in small companies with 10-49 members of staff, costs of late payments are much lower and they amount to ca. $5.5 \%$ of total costs, i.e., by ca. $1 / 3$ less than in micro companies ${ }^{17}$.

\section{Conclusion}

Based on the secondary research and analyses of major studies on reasons behind late payments, we may conclude that they entail:

1. poor financial standing of debtors who do not have enough funds and their financial difficulties or even insolvency (bankruptcy);

2. intended payment delays;

3. disputes over the quality of delivered goods and services;

4. operating (administrative) inefficiency on the side of a creditor as well as a debtor (customer).

All these reasons are universal by nature. Summing up our considerations on the negative impact of consequences and costs of late payments upon the financial performance of enterprises, we may formulate two main general and universal conclusions:

1. Payments delayed against the deadlines agreed in contracts or specified in general terms of trade between the parties surely impact the creditor's liquidity and his/ her ability to provide stable financial foundations for his/her business strategy often leading to staff dismissals or at least not hiring new staff. Hence, they are obstacles to growth especially in micro enterprises.

2. Another negative effect of late commercial payments is the need to use external financing in the credit market (loans) or borrowings for which they pay interests

17 P. Białowolski, A. Łaszek, Zatory płatnicze duży problem dla małych firm, Forum Obywatelskiego Rozwoju, Warszawa 2017, pp. 25-26. 
or raise funds in the capital market (corporate bonds), any of which influences profitability of their respective businesses as well as profitability of the capital they use.

\section{Bibliography}

1. Atradius, Payment Practices Barometer 2015/2016/2017. Survey Results for Eastern Europe.,http://global.atradius.com/, accessed on 31.05.2017.

2. Atradius, Payment Practices Barometer 2015/2016/2017. Survey Results for Western Europe http://global.atradius.com/, accessed on 31.05.2017.

3. Atradius, Barometr Praktyk Płatniczych, Polska najważniejsze wyniki 2014/2015/ 2016/2017, accessed on 31.05.2017.

4. Białowolski P., Łaszek A., Zatory płatnicze duży problem dla małych firm, Forum Obywatelskiego Rozwoju, Warszawa 2017.

5. BIG Infomonitor, Raport Indeks Zatorów Płatniczych, December 2016.

6. BIG Informonitor, Kantar Millwardbrown, Zatory Płatnicze w Polsce badanie, Warszawa 2017. BIG Informonitor, Kerella Reserarch, Praktyki korzystania z Biur Informacji Gospodarczej przez MŚP, internal info.

7. BIK, press release: Struktura i jakość kredytów firmowych mikroprzedsiębiorców w Polsce, https://media.bik.pl/informacje-prasowe/att/983454, accessed on 12 May 2017.

8. Bisnode Dun \& Bradstreet, Barometr płatności na świecie 2017, www.bisnode.pl/blog/ terminowosc-platnosci.../barometr-platnosci-na-swiecie, accessed on 20 May 2017.

9. Directive of the European Parliament and of the Council 2011/7/EU of 16.02.2011 on combating late payment in commercial transactions, OJEC.L.2011.48.1, with further amendments, Brussels, 2011.

10. Grzelczak S., Ochrona praw wierzycieli w Polsce. Kwestia transparentności i dostępności informacji, Biuletyn PTE no. 4/2016.

11. Intrum Justitia, European Payment Index 2014-2017, http://www.intrum.com, accessed on 17.06.17.

12. KRD i KPF, Portfel należności polskich przedsiębiorstw, January 2017.

13. Masiukiewicz P., Modele pomiaru i skala zatorów płatniczych w Europie, Biuletyn PTE no. 10/2016 (b).

14. Masiukiewicz P., Zatory płatnicze a ochrona praw wierzycieli. Raport cząstkowy no. III/2016 z pracy badawczej, SGH Warszawa 2017.

15. Mączyńska E., Ochrona praw wierzycieli w kontekście makroekonomicznych asymetrii, Biuletyn PTE no. 4(75) 2016, ISSN 1507-1383. 
16. Schizas M., Ending late payment Part 1: Taking stock, ACCA 2015a, http://www. accaglobal.com/content/dam/acca/global/PDF-technical/small-business/pol-tpelp-1stock.pdf.

17. Schizas M., Ending late payment Part 3: Reflection on the evidence, ACCA 2015a, http://www.accaglobal.com/content/dam/acca/global/PDF-technical/small-business/ pol-tp-elp-3reflections.pdf.

18. Shopovski J., Late Payments in Commercial Transactions in the European Union: Are we Getting Better? "European Journal of Scientific Research" ISSN 1450-216X / 1450202X vol. 140, no 4, July 2016, http://www.europeanjournalofscientificresearch.com.

19. Act of 8 March 2013 on payment deadlines in commercial transactions, Journal of Laws of 2013, item 403 with further amendments.

20. Act of 9 October 2015 amending the Act on payment deadlines in commercial transactions, Civil Code Act and some other acts, Journal of Laws of 2015, item 1830.

21. Ziętek - Kwaśniewska K., Terminowość płatności w transakcjach między przedsiębiorstwami w Polsce, Prace naukowe Uniwersytetu Ekonomicznego we Wrocławiu no. $436 / 2016$. 